\title{
EVOLUSI DOKTRIN PERTAHANAN INDONESIA SEBAGAI NEGARA MARITIM
}

\author{
Muhammad Khusna Bayu Hardianto ${ }^{1^{*}}$ \\ ${ }^{1}$ Pasca Sarjana Ilmu Hubungan Internasional, Fakultas Ilmu Sosial dan Ilmu \\ Politik, Universitas Indonesia \\ *Korespondensi: m.khusna@ui.ac.id
}

\begin{abstract}
Indonesia's foreign policy in the era of President Joko Widodo's administration focused on national maritime awareness. With its strategic geographic and geopolitical potential, it is realized that there are also potential threats. By using qualitative research method and the concept of Revolution on Military Affairs, this article discusses the increase and adjustment of national maritime defense posture, and also the changes in military doctrine that followed by strategic policies supporting the Revolution on Military Affairs in Indonesia as a maritime country. Adaptation of doctrine is indispensable to face new emerging threats. The Indonesian government must ensure its commitment to the Minimum Essential Forces that supports the effort to achieve defense independence.
\end{abstract}

Keywords: doctrine; military; evolution; maritime; defense; Indonesia

\begin{abstract}
ABSTRAK
Kebijakan Luar Negeri Indonesia di era pemerintahan Presiden Joko Widodo berfokus pada kesadaran sebagai negara maritim. Posisi Indonesia selain memiliki potensi strategis secara geografis dan geopolitik, disadari juga berpotensi mendatangkan ancaman yang besar. Dengan menggunakan metode kualitatif dan menggunakan konsep Revolution on Military Affairs, Artikel ini membahas pentingnya peningkatan dan penyesuaian postur pertahanan nasional di bidang kemaritiman di Indonesia dan melihat besarnya pengaruh perubahan doktrin militer yang diikuti oleh kebijakan-kebijakan strategis mendukung terjadinya Revolution on Military Affairs di Indonesia sebagai negara maritim. Adaptasi doktrin sangat diperlukan dalam menghadapi ancaman-ancaman baru. Pemerintah Indonesia harus memastikan komitmen pencapaian Minimum Essential Force yang mendukung pencapaian kemandirian pertahanan.
\end{abstract}

Keywords: doktrin; militer; evolusi; maritim; pertahanan; Indonesia

PENDAHULUAN

Pada masa pemerintahan

Presiden Joko Widodo, Kebijakan Luar

Negeri Indonesia berfokus pada kesadaran bahwa Indonesia merupakan sebuah negara kepulauan. Posisi Indonesia sangat strategis secara geografis, geopolitik dan geoekonomi baik di tingkat regional maupun global 
(Badan Nasional Pengelolaan Perbatasan RI, 2015).

Selain memiliki peluang untuk maju melalui ambisi Poros Maritim Dunia, Indonesia juga menghadapi ancaman yang besar. Mulai dari masalah klasik sengketa perbatasan, hingga masalah kejahatan lintas batas atau kejahatan transnasional seperti terorisme, perompakan dan pembajakan di laut, perdagangan manusia, penyelundupan dan peredaran narkoba.

Dari sisi pertahanan, Indonesia sebagai negara maritim belum memiliki kemampuan yang memadai untuk mengamankan seluruh wilayah kedaulatannya. Jumlah dan jenis alat utama sistem pertahanan (alutsista) belum sebanding dengan luas wilayah negara. Kementerian Pertahanan (Kemhan) dan Tentara Nasional Indonesia (TNI) mau tidak mau harus berupaya menghadapi dan mengimbangi ancaman. Salah satu yang menjadi tuntutan bagi kedua lembaga pertahanan negara yaitu kemampuan untuk melakukan adaptasi strategi militer. Komitmen pemerintah dalam melanjutkan program pembangunan postur pertahanan dan meningkatkan kemampuan pertahanan nasional diwujudkan dalam berbagai kerja sama yang terjalin antara Indonesia dengan negara-negara sahabat, dengan harapan bahwa kerja sama tersebut dapat saling menguntungkan. Selain itu, sebagaimana disampaikan oleh Menteri BUMN Rini Soemarno, pembangunan infrastruktur, konektivitas maritim, industri perkapalan termasuk peralatan pertahanan keamanan harus menjadi prioritas. Hal ini merupakan bentuk perwujudan kesadaran Indonesia sebagai negara maritim untuk meningkatkan kekuatan dan pertahanan laut.

Artikel ini menjelaskan perubahan-perubahan doktrin militer yang terjadi di Indonesia dan Penelitian yang dilakukan bertujuan untuk memahami sistem pertahanan Indonesia, terutama di era pemerintahan Presiden Joko Widodo yang berfokus pada keamanan maritim dan pertahanan laut.

Kajian mengenai aspek pertahanan negara dan Revolution on Military Affairs (RMA) telah banyak dilakukan, meski demikian, kajian 
mendalam yang berkaitan dengan RMA di Indonesia masih sedikit terbatas. Di antara berbagai tulisan yang membahas kemandirian pertahanan dan RMA Indonesia, penulis mencoba mengumpulkan literatur-literatur yang relevan dengan isu tersebut. Literatur-literatur yang ditemukan antara lain membahas mengenai aspek pertahanan negara dan RMA Indonesia dalam beberapa pandangan sebagai berikut.

\section{Pertama, tulisan yang} membahas sistem pertahanan dikaitkan dengan Indonesia sebagai negara maritim (Darmawan et al., 2020), (Putra A \& Pramono, 2004), (Tjoneng, 2017). Kedua, tulisan yang membahas mengenai RMA Indonesia sebagai negara maritim (Herdijanto et al., 2019), ketiga tulisan yang membahas strategi pemerintah Indonesia dalam upayanya memenuhi Minimum Essential Force (MEF) (Rahman et al., 2015)(Djarwono, 2017) dan yang keempat yaitu tulisan yang membahas tentang kemandirian pertahanan Indonesia (Indrawan \& Widiyanto, 2016) (Susdarwono, 2014) (Montratama, 2018) (Hartati et al., 2014) .
Dari berbagai literatur di atas, penulis menyimpulkan bahwa RMA atau Revolusi Teknologi Persenjataan di Indonesia berkaitan erat dengan upaya negara untuk memenuhi MEF, mencapai cita-cita membangun poros maritim dunia, dan upaya negara dalam menghadapi munculnya ancamanancaman baru. Kemudian disamping hal-hal tersebut di atas, penulis juga menemukan beberapa literatur yang membahas mengenai kemandirian pertahanan Indonesia. Ada penelitian yang membahas kaitan antara adaptasi doktrin militer dan RMA di Indonesia yang mengarah pada cita-cita poros maritim dunia. Hal ini dipandang penting untuk diteliti dalam rangka memahami sejauh mana perubahan doktrin yang terjadi di Indonesia sebagai negara maritim.

Menurut Krepinevich, Revolution in Military Affairs (RMA) adalah sebuah konsep di mana teknologi baru, inovasi konsep operasi, dan adaptasi organisasi militer diaplikasikan secara bersamaan sehingga menghasilkan peningkatan kekuatan dan efektivitas angkatan bersenjata yang signifikan (Andrew F. Krepinevich, 1994). 
Dalam konsep yang dikemukakan oleh Andrew Marshall, disebutkan bahwa RMA merupakan perubahan yang terjadi pada teknologi persenjataan dan memberi pengaruh terhadap aspek-aspek lain seperti konsep organisasi, struktur militer, dan juga doktrin militer. Teknologi baru akan menyebabkan perubahan dalam cara berperang (Maloney, Sean M.; Robertson, 1999 p.445). Konsep RMA berasumsi dasar bahwa senjata memiliki pengaruh yang signifikan terhadap kekuatan negara yang kemudian menjadi dasar terbentuknya perilaku negara tersebut. Teknologi persenjataan menjadi instrumen yang membuat sebuah negara dinilai lebih unggul apabila dibandingkan dengan negara lain. RMA yang terjadi pada suatu negara sangat berkaitan dengan modernisasi teknologi dan militer yang berhubungan dengan kepentingan dan keamanan nasional. Selain itu, RMA dalam suatu negara digambarkan sebagai kaitan antara teknologi dan sistem persenjataan canggih atau hardware, doktrin militer atau software, serta struktur organisasi militer atau wetware (Dombrowski, 2008).
Perkembangan

teknologi informasi dan komunikasi yang semakin pesat memberi pengaruh terhadap bentuk dan sifat perang di dunia. Teknologi mengambil peran dominan dalam peperangan di lapangan dan juga mempengaruhi perubahan bentuk ancaman terhadap keamanan negara. Adanya perkembangan ini dapat dilihat sebagai sebuah bentuk kelangsungan RMA.

\section{METODE}

Artikel ini menggunakan metode penelitian kualitatif dengan pendekatan deduktif. Metode ini digunakan dalam penelitian yang secara epistemologis bersifat interpretivis dan secara ontologis bersifat konstruktivis. Menurut Cristopher Lamont, penelitian kualitatif merupakan penelitian yang dilakukan atas sekumpulan data dan strategi analisis yang menggunakan data non-numerik (Lamont, 2015). Penelitian kualitatif ini dilakukan dengan harapan dapat memberikan pemahaman terhadap suatu fenomena yang terjadi di dalam ruang lingkup politik internasional. Selanjutnya, pemahaman tersebut akan mengarah pada analisis terhadap faktor-faktor 
yang berpengaruh pada fenomena yang ada.

Penelitian ini dilakukan dengan menggunakan metode pengumpulan data dan analisis terhadap data-data yang ada. Data dikumpulkan dari berbagai naskah, dokumen, buku, jurnal, laporan, media massa, dan website. Teknik pengumpulan data yang digunakan yaitu penelitian berbasis internet. Informasi-informasi digali dari sumber-sumber terpercaya seperti website resmi lembaga pemerintahan, kantor berita dan jurnal online yang memiliki reputasi baik, dan dokumen-dokumen elektronik lainnya. Teknik pengumpulan data berbasis internet dipilih karena berbagai informasi yang resmi dan akurat, yang menjadi sumber referensi penelitian dapat dengan mudah dan cepat ditemukan.

\section{HASIL DAN PEMBAHASAN}

\section{REVOLUSI MILITER INDONESIA}

DI

Pembahasan mengenai
Revolusi Militer yang terjadi di
Indonesia dalam konteks tulisan ini
yaitu terkait perubahan dalam doktrin

militer TNI. Untuk memahami sejauh mana perubahan doktrin yang terjadi di Indonesia sebagai negara maritim, pertama-tama penting untuk melihat perkembangan dan arah kebijakan pertahanan negara.

Perkembangan angkatan bersenjata Indonesia sejak masa kemerdekaan hingga era globalisasi pasca perang dingin merupakan sejarah yang panjang. Berbagai perubahan dan dinamika ancaman yang dihadapi Indonesia mau tidak mau harus dihadapi dan disikapi dengan berbagai penyesuaian dalam tubuh angkatan bersenjata yaitu Tentara Nasional Indonesia (TNI). Dalam sistem pertahanan Indonesia, sebagaimana diatur dalam Undang-Undang Nomor 3 Tahun 2002 tentang Pertahanan Negara, TNI menjadi komponen utama negara dalam menghadapi ancaman militer. Dalam rangka melaksanakan fungsi sebagai komponen utama tersebut, TNI didukung oleh adanya komponen cadangan dan komponen pendukung (Ministry of Defence of the Republic of Indonesia, 2015). Sedangkan dalam menghadapi ancaman non-militer yang berdimensi ideologi, politik, ekonomi, sosial 
budaya, teknologi, keselamatan umum, dan ancaman-ancaman lain yang berdimensi legislasi, Kementerian/ Lembaga di luar bidang pertahanan menjadi unsur utama dengan dibantu unsur-unsur kekuatan bangsa lainnya (UNDANG-UNDANG REPUBLIK INDONESIA NOMOR 16 TAHUN 2012 TENTANG INDUSTRI PERTAHANAN Pasal 7, 2012).

\section{Perubahan Doktrin TNI}

TNI menyikapi perkembangan ancaman yang dihadapi dengan penyesuaian-penyesuaian yang meliputi pembaruan doktrin militer dan perubahan struktur organisasi. Sejak terbentuknya TNI yang bermula dari Badan Keamanan Rakyat pada tahun 1945, doktrin militer Indonesia telah mengalami beberapa kali perubahan Menurut Widjajanto, evolusi doktrin pertahanan Indonesia dibagi dalam enam periode, yaitu Periode Perang Kemerdekaan (1945-1949), Periode Republik Indonesia Serikat/RIS (19491950), Periode Perang Internal (19501959), Periode Demokrasi Terpimpin (1959-1967), Periode Orde Baru (1967-1998), dan terakhir yaitu Periode Reformasi (1998-2004) (Widjajanto, 2004). Namun seiring perkembangannya, setelah ke-enam Periode tersebut, Panglima TNI mengesahkan Peraturan yang meliputi Doktrin Tri Darma Eka Karma pada tahun 2010. Disahkannya doktrin ini merupakan bentuk penyesuaian terhadap dinamika politik dan keamanan yang dihadapi oleh negara.

Pada tahun 1954, pemerintah saat itu melalui Undang-Undang Nomor 29 Tahun 1954 mencetuskan konsep Sistem Pertahanan Semesta yang digagas sebagai Doktrin Pertahanan Rakyat. Kemudian pada era peralihan dari orde lama ke orde baru, di bawah pemerintahan Presiden Soeharto tahun 1966, Doktrin Tri Ubaya Çakti dicetuskan sebagai doktrin perjuangan pertama Indonesia. Secara garis besar, doktrin ini menggunakan Strategi Militer Pertahanan Rakyat Semesta (Perata) yang digagas oleh Angkatan Darat. Doktrin Tri Ubaya Çakti ini menggunakan strategi pemanfaatan rakyat sebagai fungsi komponen cadangan untuk membantu militer jika terjadi perang. Pola pembinaan Perata terbagi menjadi dua yaitu Pembinaan Wilayah dan Pembinaan Teritorial. 
Di tahun yang sama, Markas Besar Hankam juga mengeluarkan Doktrin Catur Darma Eka Karma 1966. Doktrin ini merupakan doktrin perjuangan yang kemudian disebut sebagai Doktrin Induk Militer Indonesia. Secara garis besar, penyatuan Polri dengan Angkatan Bersenjata Republik Indonesia (ABRI) yang menunjukkan adanya strategi pertahanan terhadap ancaman dari dalam negeri, merupakan hal paling signifikan dalam doktrin tersebut.

Selanjutnya pada tahun 1988, Doktrin Induk Catur Darma Eka Karma 1988, yang masih menggunakan sistem pertahanan rakyat semesta, ditetapkan sebagai doktrin militer yang baru. Dalam doktrin ini disebutkan bahwa upaya pertahanan negara meliputi sistem pertahanan, politik pertahanan, dan strategi pertahanan. Pada era ini, Doktrin Penampilan TNI-ABRI Sad Daya Dwi Bakti 1994 menjadi doktrin pelaksana dari Doktrin Induk Catur Darma Eka Karma 1988. Dalam perkembangan politik dan keamanan negara, TNI dan Polri sejak tahun 2000 ditetapkan untuk tidak lagi berada dalam satu organisasi ABRI.
Menyusul hal tersebut, kemudian diterbitkanlah UndangUndang RI No. 3 Tahun 2002 tentang Pertahanan Negara dan UndangUndang RI Nomor 34 Tahun 2004 tentang TNI. Selanjutnya pada tahun 2007, Panglima TNI mengeluarkan Keputusan tentang Doktrin TNI yang baru yaitu Tri Darma Eka Karma dan Menteri Pertahanan pada tahun 2007 mengeluarkan Peraturan Menteri tentang Doktrin Pertahanan Negara. Doktrin tersebut kemudian disahkan pada tahun 2010 melalui Peraturan Panglima TNI.

\section{Doktrin Pertahanan Maritim}

Sebagai sebuah negara yang memiliki letak geografis yang strategis dengan potensi sumber daya yang dimilikinya, Indonesia tidak akan pernah lepas dari berbagai ancaman baik militer maupun non-militer. Masalah-masalah perbatasan, wilayah kedaulatan dan keamanan laut semakin hari semakin menjadi fokus utama bagi Indonesia. Sebagaimana tercantum dalam Buku Putih Pertahanan Indonesia tahun 2008, prioritas ancaman berfokus pada keamanan wilayah maritim, terutama di wilayahwilayah perbatasan. Potensi ancaman 
tersebut menuntut pertahanan negara yang cukup kuat dan mampu menjangkau seluruh wilayah secara maksimal (Kementerian Pertahanan RI, 2008 p.53). Mengingat luas wilayah dan panjang garis batas negara yang sebagian besar merupakan wilayah perairan, kesadaran dan pola pikir kemaritiman mutlak dimiliki oleh Indonesia.

Kembali pada masa-masa pasca kemerdekaan, doktrin mengenai kekuatan militer Angkatan Laut yaitu Doktrin Eka Sasana Jaya sebenarnya telah ditetapkan pada tahun 1965 Doktrin tersebut relevan dengan semangat perjuangan pembebasan Irian Barat dan adanya konfrontasi dengan Malaysia pada saat itu. Namun pada era Orde Baru, dengan ditetapkannya Doktrin Induk, maka doktrin setiap matra kemudian menjadi tidak digunakan lagi.

Hingga akhirnya pada era setelah reformasi, menyusul pemisahan TNI dan Polri serta penghapusan Dwi Fungsi ABRI, Doktrin Eka Sasana Jaya kembali digunakan. Adaptasi terhadap doktrin tersebut dilakukan pada tahun 2001. Sejak saat itu, semakin hari kesadaran Indonesia sebagai bangsa maritim semakin tumbuh dan pemerintah mulai memperhatikan batas wilayah teritorial di laut dan pulau-pulau terluar, doktrin tersebut tampak semakin relevan. Hal ini merupakan bentuk perubahan doktrin yang bertujuan untuk memperkuat sistem pertahanan negara.

Sejalan dengan hal tersebut, dalam Doktrin Tri Darma Eka Karma sebagai doktrin induk TNI, disebutkan mengenai sistem pertahanan semesta di mana fokus pertahanan Indonesia mengarah pada penguatan aspek maritim. Negara berupaya melakukan pemenuhan kekuatan pertahanan di seluruh wilayah negara sesuai kondisi geografis sebagai satu kesatuan pertahanan (Kementerian Pertahanan RI, 2008 p.43).

Selain itu, dalam Doktrin Induk tersebut juga disebutkan mengenai sistem Operasi Militer untuk Perang (OMP) dan Operasi Militer Selain Perang (OMSP). Kekuatan TNI untuk melaksanakan OMSP akan digunakan jika terjadi peningkatan ancaman seperti misalnya pelanggaran wilayah oleh negara lain (Kementerian Pertahanan RI, 2008 pp.50-51). Hal ini semakin memperjelas pentingnya 
peningkatan kekuatan pertahanan maritim Indonesia. Kebutuhan akan senjata dan kapal-kapal berteknologi tinggi sangat diperlukan untuk melakukan deteksi dan penindakan pelanggaran serta penegakan hukum di laut.

Peningkatan prioritas

kemaritiman Indonesia berjalan seiring dengan kebijakan pencapaian $\mathrm{MEF}$ yang berujung pada terpenuhinya kekuatan minimum yang dibutuhkan negara. Kebijakan MEF Indonesia dimulai sejak tahun 2009 (Humas PT. PAL, 2019). Kebijakan tersebut dibagi ke dalam tiga tahap (periode 5 tahunan) sepanjang tahun 2009 hingga 2024. Pada tahap pertama 2009-2014, tahap kedua tahun 2014-2019, dan tahap ketiga pada tahun 2019-2024. Kebijakan MEF yang di dalamnya termasuk pemenuhan kebutuhan alutsista maritim ini mendapat dukungan konsisten dan cenderung meningkat dari anggaran pertahanan setiap tahunnya. Hal ini menunjukkan keseriusan pemerintah dalam memperkuat pertahanan negara.

SIMPULAN
Kebijakan Luar Negeri Indonesia di era pemerintahan Presiden Joko Widodo berfokus pada upaya membangkitkan kembali kesadaran Indonesia sebagai sebuah negara maritim. Indonesia memiliki posisi strategis dan sangat berpengaruh secara geopolitik yang harus memperhatikan potensi peluang dan ancaman. Indonesia sebagai negara maritim harus meningkatkan kemampuan untuk melindungi wilayah kedaulatannya.

Adaptasi doktrin dan strategi militer dilakukan guna mengimbangi potensi ancaman yang akan dihadapi. Selain itu, program pemerintah dalam pembangunan postur pertahanan dan peningkatan kemampuan pertahanan nasional juga diwujudkan dalam berbagai kerja sama bilateral yang saling menguntungkan. Peningkatan infrastruktur dan konektivitas maritim dalam negeri, serta perkembangan industri manufaktur penunjang pertahanan dan kemaritiman seperti industri perkapalan, industri persenjataan dan kedirgantaraan merupakan modal kunci yang telah dimiliki Indonesia. Hal ini akan mendukung perwujudan upaya 
Indonesia dalam menuju kemandirian pertahanan.

Perubahan doktrin militer di Indonesia yang tidak pernah lepas dari dinamika politik. Pada era kepemimpinan Presiden Suharto, dominasi Angkatan Darat dalam pemerintahan yang berkuasa selama beberapa dekade membuat Indonesia tidak memprioritaskan kebutuhan sebagai negara maritim. Era Reformasi menjadi salah satu titik balik perubahan yang secara bertahap memunculkan kembali doktrin kekuatan pertahanan maritim dan berlangsung secara berkesinambungan, sejalan dengan proses pengembangan kekuatan pertahanan negara melalui upaya pencapaian MEF hingga tahun 2024.

Meskipun perubahan doktrin yang dibahas dalam tulisan ini hanyalah satu komponen dari tiga kriteria RMA, namun dalam perubahan-perubahan doktrin TNI yang terjadi, struktur dan organisasi militer mendapatkan pengaruh berupa perubahan yang sangat besar, terutama sejak pasca Reformasi.
Di era globalisasi yang sarat dengan perkembangan teknologi informasi, terdapat kecenderungan adanya ancaman gangguan keamanan global, regional dan nasional baru berupa ancaman non-militer. Ancaman tersebut dilakukan oleh aktor nonnegara akan tetapi sangat berpotensi mengganggu keamanan publik dan memberikan pengaruh besar bagi negara. Apabila gangguan tersebut tidak segera diatasi dan diantisipasi, dikhawatirkan akan terjadi peningkatan gangguan menjadi ancaman nyata yang dapat berpengaruh pada keamanan negara.

Ancaman keamanan yang baru dan sedang dihadapi negara saat ini antara lain terorisme, radikalisme, gerakan separatis, pemberontakan bersenjata, bencana alam, wabah penyakit, pelanggaran teritorial, perompakan dan pembajakan di laut, pencurian sumber daya alam, kejahatan siber dan spionase, penyelundupan serta peredaran narkotika. Selain itu, adanya kerawanan di lingkup geopolitik kawasan, salah satunya kemungkinan eskalasi konflik di wilayah-wilayah perbatasan yang rentan tentunya juga menjadi salah satu 
pertimbangan bagi pemerintah untuk memprioritaskan pertahanan maritim.

Fokus pemerintah saat ini di bidang kemaritiman dinilai tepat dengan menyadari kenyataan Indonesia sebagai negara maritim dan memperhatikan situasi geopolitik yang berkembang. Adaptasi dan perubahan doktrin di masa yang akan datang sangat diperlukan mengingat perkembangan ancaman serta peluang munculnya ancaman-ancaman baru. Pemerintah Indonesia harus memastikan komitmen pencapaian MEF pada tahun 2024 dan secara bertahap meningkatkan kemampuan industri dalam negeri yang mendukung pencapaian kemandirian pertahanan.

\section{DAFTAR PUSTAKA}

Agung, D. (n.d.). MENATA

PANGKALAN ANGKATAN LAUT GUNA MEMPERKUAT KEDAULATAN MARITIM INDONESIA Oleh: Darma Agung S. I., M.Si (Han) 1 dan Hollanda Arief K., M.Si 2. 1-15.

Andrew F. Krepinevich. (1994). Cavalry to Computer. The National Interest, 37(37), 30-42.

Badan Nasional Pengelolaan Perbatasan RI. (2015). Peraturan BNPP No. 1/2015.

Darmawan, W., Alkadrie, J., \&
Sudirman, A. (2020). Kerjasama Kementerian Pertahanan Republik Indonesia Daewoo Shipbuilding Marine Enginering dalam Pengadaan Kapal Selam sebagai Upaya Pemenuhan Minimum Essential Force Militer Republik Indonesia. Padjadjaran Journal of International Relations, 1(4), 303.

https://doi.org/10.24198/padjir.v1i 4.26242

Djarwono, L. F. (2017). Pembangunan Industri Pertahanan Indonesia: Menuju Pemenuhan Target Mef Atau Sekedar Menuju Arm Candy? Defendonesia, 2(2), 2534.

Dombrowski, P. (2008). The Revolution in Military Affairs, Transformation and the Defence Industry. Security Challenges, 4(4), 13-38.

Hartati, S., Muhammad, A., Bayu, K., \& Tasrif, M. (2014). Indonesian Defense Industry Model Concept: A Study Framework for Defense Industry Building. Journal of Advanced Management Science, 2(4), 260-266. https://doi.org/10.12720/joams.2. 4.260-266

Herdijanto, T., Mulyadi, \& Susilo, A. K. (2019). Development Strategy of Revolution in Military Affair Concept By Indonesia Armed Forces (Tni) in the South China Sea. Journal of Defense Resources Management, 10(2), 40-61. https://search.proquest.com/docvi ew/2339150412? accountid $=1724$ 2

Humas PT. PAL. (2019). Kebijakan 
Modernisasi Alutsista Laut

Berbasis MEF Tahap III - PT.

PAL Indonesia (Persero). https://pal.co.id/2020/02/publikasi /artikel/kebijakan-modernisasialutsista-laut-berbasis-mef-tahapiii/

Indrawan, R. M. J., \& Widiyanto, B. (2016). KEBIJAKAN OFSET DALAM MEMBANGUN KEMANDIRIAN PERTAHANAN NEGARA. Jurnal Pertahanan, 6(2), 29-50.

Kementerian Pertahanan RI. (2008). Buku Putih Pertahanan Indonesia 2008.

Lamont, C. (2015). Research Methods in International Relations. Sage.

Maloney, S. M., \& Robertson, S. (1999). The Revolution in Military Affairs. War in the Modern World, 1990-2014, 54(3), 6-12. https://doi.org/10.4324/97813157 53614-2

Ministry of Defence of the Republic of Indonesia. (2015). KEBIJAKAN PERTAHANAN NEGARA TAHUN 201 6. In Journal of Chemical Information and Modeling.

Montratama, I. (2018). Strategi Optimalisasi Pengadaan Sarana Pertahanan Bagi Industri Pertahanan Indonesia. Jurnal Pertahanan \& Bela Negara, 4(3). https://doi.org/10.33172/jpbh.v4i3 .342

Puspen TNI. (2007). Konsepsi Strategi Pertahanan Negara Sesuai Doktrin Tni Tri Dharma Eka Karma (Tridek)_Website
Tentara Nasional Indonesia. https://tni.mil.id/view-5131konsepsi-strategi-pertahanannegara-sesuai-doktrin-tni-tridharma-eka-karmatridek.html\#: :text=Sesuai Doktrin TNI Tri Dharma Eka Karma (Tridek)\%2C strategi,a.

Putra A, I. N., \& Pramono, S. H. (2004). KONSEPSI PEMBANGUNAN KEKUATAN DAN KEMAMPUAN SISTEM INFORMASI OPERASI TNI AL DALAM MENDUKUNG PENYELENGGARAAN STRATEGI PERTAHANAN LAUT NUSANTARA. Asro STTAL, 11 .

Rahman, A. F., Anwar, S., Arwin, D., $\&$ Sumari, D. (2015). Analisis Minimum Essential Force (Mef) Dalam Rangka Pembangunan Cyber-Defense 1 Analysis of Minimum Essential Force (Mef) in Building Cyber-Defense. Jurnal Pertahanan Desember, 5, 63.

https://www.cia.gov/library/publi cations/the-world-

Susdarwono, E. T. (2014). Ekonomi Politik Pengadaan Alutsista Kapal Selam Changbogo dalam Rangka Menuju Proses Kemandirian Industri Pertahanan Indonesia.

Tjoneng, A. (2017). Mewujudkan Indonesia sebagai Negara Poros Maritim Dunia. Dialogia Iuridica: Jurnal Hukum Bisnis Dan Investasi, 7(1), 47. https://doi.org/10.28932/di.v7il.7 08

UNDANG-UNDANG REPUBLIK INDONESIA NOMOR 16 TAHUN 
2012 TENTANG INDUSTRI

PERTAHANAN. (2012).

Widjajanto, A. (2004). Evolusi Doktrin

Pertahanan Indonesia. 1-31.

Sumber lain:

https://www.kemhan.go.id/2016/11/03/

menhan-indonesia-harus-membangun-

kekuatan-pertahanan-maritim.html

\section{PROFIL SINGKAT}

Penulis yang lahir pada 31 Desember 1983, merupakan Sarjana Ilmu Politik lulusan Program Studi Ilmu Hubungan Internasional Universitas Pembangunan Nasional "Veteran" Yogyakarta tahun 2009. Saat ini penulis sedang menyelesaikan program Pasca Sarjana Ilmu Hubungan Internasional di Universitas Indonesia. 